\title{
THYMOCYTE APOPTOSIS AND PROLIFERATION MODELING DURING RAT THYMIC INVOLUTION IS INFLUENCED BY OVARIAN HORMONES IN A THYMOCYTE SUBSET-SPECIFIC MANNER
}
ARSENOVIĆ-RANIN NEVENA*, NACKA-ALEKSIĆ MIRJANA*, DJIKIĆ JASMINA*, PERIŠIĆ MILICA**, KOSEC D ${ }^{\star *}$, PILIPOVIĆ I**, STOJIĆ-VUKANIĆ ZORICA* and LEPOSAVIĆ GORDANA*

*University of Belgrade, Faculty of Pharmacy, Serbia; **Institute of Virology, Vaccines and Sera
"Torlak", Immunology Research Centre "Branislav Janković", Serbia

(Received $4^{\text {th }}$ September 2012)

The study was aimed to define the putative role of ovarian hormones in shaping thymocyte apoptosis and proliferation during thymic involution. Thymocytes from young adult and middle-aged rats ovariectomized (Ox) before puberty were examined for apoptosis and proliferation. Apoptosis and proliferation were measured in fresh thymocyte suspensions and in their 18-hour cultures, and fresh thymocyte suspensions, respectively. The thymocyte population and the major thymocyte subsets were analyzed following triple staining using anti-CD4 and anti-CD8 monoclonal antibodies and 7-AAD to label apoptotic or proliferating cells. The frequency of apoptotic cells was lower in thymocyte suspensions and cultures from Ox rats of both ages. This reflected in a diminished frequency of apoptotic cells amongst $C D 4+C D 8+$ double positive $(D P)$ and $C D 4+C D 8$ - single positive (SP), and $D P$ cells in young and middle-aged Ox rats, respectively. Additionally, in thymocyte cultures from $\mathrm{Ox}$ rats the frequency of apoptotic cells amongst CD4+CD8- and CD4-CD8+ SP cells decreased with age, but increased within DP and CD4-CD8- double negative $(D N)$ subsets, reaching in the former subset from middle-aged Ox rats higher values than in age-matched controls. The frequency of proliferating cells was also lower in Ox rats than in controls. This reflected the lower frequency of cycling cells amongst CD4+CD8- SP and CD4-CD8 + SP thymocytes in young rats, and DP and CD4-CD8+ $S P$ thymocytes in middle-aged rats. Besides, in both $S P$ and $D P$ thymocyte subsets from Ox rats the frequency of proliferating cells declined with age. In conclusion, thymocyte apoptosis and proliferation exhibit ovarian hormone-dependent thymocyte subset specific alterations during thymic involution.

Key words: ovariectomy, thymic involution, thymocyte apoptosis, thymocyte proliferation 
Acta Veterinaria (Beograd), Vol. 63, No. 1, 3-21, 2013.

Arsenović-Ranin Nevena: Thymocyte apoptosis and proliferation modeling during rat thymic involution is influenced by ovarian hormones in a thymocyte subset-specific manner

\section{INTRODUCTION}

The link between sex steroids and thymic involution has been extensively investigated, but still remains a complex puzzle with missing pieces. Thymus, a specialized site for T-cell development, undergoes substantial age-associated morphological and functional changes, eventually leading to a decline in output of newly generated naïve T cells and, consequently, alterations in adaptive immunity. These changes are responsible for the increased susceptibility to infectious diseases, greater incidence of malignant and autoimmune diseases and poor response to vaccines in the elderly (Pawelec et al., 2005; Rose, 1994; Gruver et al., 2007). It is generally accepted that in rodents the onset or, at least, dramatic acceleration of thymic involution takes place at puberty (Linton and Dorshkind, 2004). However, the cellular and molecular mechanisms underlying this process are not completely understood, yet. The better understanding of these mechanisms will not only contribute to the understanding of basic cellular and molecular mechanisms underlying age-related immune changes, but it could enable us to formulate some new strategies to postpone and/or moderate agerelated decline in immune responsiveness.

The development of T-cells is a complex process involving thymocyte proliferation, apoptosis and differentiational marker expression. Prothymocytes seed the thymus and pass through multiple stages, from the earliest CD4-CD8double negative (DN) stage, to CD4+CD8+ double positive (DP) stage and ultimately, following rigorous selection processes, to mature CD4+CD8- or CD4CD8+ single positive (SP) stage (Jameson et al., 1995). During positive selection, thymocytes convert from a DP phenotype to a CD4+CD8- or a CD4-CD8+ SP cells (Jameson et al., 1995). The majority of thymocytes will not undergo positive selection, but will die by apoptosis within the thymus (Surh and Sprent, 1994). Thymocytes that express a functional TCR $\alpha \beta$ but are potentially autoreactive will die by apoptosis as a result of negative selection. Thymocytes that do not express a functional TCR cannot undergo positive or negative selection. This nonselected population also dies by apoptosis (Surh and Sprent, 1994). Along thymocyte developing route, cell proliferation takes place at several points from DN to SP stage, but thymocyte expansion is most extensive at the transition from DN to DP developmental stage (Surh and Sprent, 1994).

The overall thymocyte number is determined not only by the progenitor entry, but also by thymocyte apoptosis and proliferation rate. Both of these processes are shown to exhibit age-related changes. In the rat thymus, thymocyte apoptosis is most prominent after 2-4 weeks of life (Quaglino et al., 2001). Incorporation of thymidine in female rat thymocytes peaks during the second month of life, and starts to decline after 6 months (Segal et al., 1985). However, mechanisms standing behind the aforementioned age-related thymocyte changes are still largely unknown.

There is an accumulating body of evidence indicating that pregnancy, as well as estrogen treatment can induce a significant thymic atrophy in rodents (Kuhl et al,. 1983; Silverstone et al., 1994; Staples et al., 1998). On the other hand, it has been shown that in rodents prepubertal ovariectomy postpones age- 
Arsenović-Ranin Nevena: Thymocyte apoptosis and proliferation modeling during rat

thymic involution is influenced by ovarian hormones in a thymocyte subset-specific manner

associated thymic involution, whereas ovariectomy in adults leads to reversal of thymic involutive changes and a significant increase in the overall thymocyte number (Leposavic and Perisic, 2008; Perisic et al., 2010). However, it should be pointed that the data on the effects of the extended ovarian hormone deprivation on thymic involution are limited.

Moreover, there are findings indicating that ovarian hormones influence the size of the thymocyte pool by affecting the proliferation of these cells (Zoller and Kersh, 2006; Zoller et al., 2007). The available data on the influence of ovarian hormones on thymocyte apoptosis and proliferation are inconsistent (Okasha et al., 2001; Zoller et al., 2007). Okasha et al. (2001) showed direct proapoptotic estradiol action on thymocytes. On the other hand, during pregnancy significant changes in thymocyte apoptosis within any of the major thymocyte subsets were not detected (Zoller and Kersh, 2006). Moreover, both estrogen anti-proliferative (Zoller et al., 2007) and stimulatory effects (Brunelli et al., 1992) on thymocyte subset proliferation have been reported.

Considering the all aforementioned, the present study was undertaken to elucidate the putative role of ovarian hormones in determining proliferative and apoptotic capacity of the major thymocyte subsets during thymic involution. To this end, rats were ovariectomized $(\mathrm{Ox})$ at the age of 1 month, and thymocyte apoptosis and proliferation were examined within the major thymocyte subsets delineated by CD4/CD8 expression in freshly isolated thymocyte suspensions and in thymocyte cultures from young sexually mature (2-months-old) and middle-aged (11-months-old) rats, showing signs of an advanced thymic involution (Perisic et al., 2010).

\section{MATERIALS AND METHODS}

\section{Animals}

Female Albino Oxford (AO) rats used in the study were born and bred in the animal housing facility at the Immunology Research Centre "Branislav Janković" in Belgrade. All animals were housed in polyurethane boxes at constant temperature $\left(22 \pm 1^{\circ} \mathrm{C}\right)$ on a 12-h light/dark cycle with lights starting at 07:00 am. They had free access to standard laboratory chow and tap water. All experimental procedures involving animals and their care were in accordance with the Directive 2010/63/EU of the European Parliament and of the Council on the protection of animals used for scientific purposes (revising Directive 86/609/EEC). The experimental protocol was approved by the Experimental Animal Committee of the Immunology Research Centre "Branislav Janković".

\section{Experimental design}

One-month-old prepubertal rats were randomly assigned to ovariectomy and sham-ovariectomy. One and ten months afterwards, both Ox and sham-Ox rats were sacrificed. Each group consisted of 6 animals. 
Acta Veterinaria (Beograd), Vol. 63, No. 1, 3-21, 2013.

Arsenović-Ranin Nevena: Thymocyte apoptosis and proliferation modeling during rat thymic involution is influenced by ovarian hormones in a thymocyte subset-specific manner

\section{Surgical procedure}

All animals were anaesthetized with i.p. injection $(0.8 \mathrm{~mL} 100 \mathrm{~g} / \mathrm{b} . \mathrm{w}$.$) of$ solution containing ketamine $\left(100 \mathrm{mg} / \mathrm{mL}\right.$, Ketamidor ${ }^{\circledR}$, Richter Pharma AG, Austria), xylazine $\left(20 \mathrm{mg} / \mathrm{mL}\right.$, Xylased ${ }^{\circledR}$, Bioveta, Czech Republic) and saline, in a 1:0.5:8.5 ratio, and then bilaterally Ox or sham-Ox. Ovaries were removed through small dorsal incisions above the ovaries, on each side of the lumbar spine. Skin wounds were closed using surgical clips. In sham-Ox rats, the skin and muscle layers were opened, ovaries manipulated, but not excised. Given that estrogens increase uterine weight (Frasor et al., 2003), the efficiency of the ovariectomy was confirmed at autopsy by measuring uterine wet weight. All rats were euthanized by exposure to increasing concentrations of $\mathrm{CO}_{2}$ (between 09:00 and 10:00 h).

Chemicals, antibodies and immunoconjugates

Sodium azide $\left(\mathrm{NaN}_{3}\right)$ was purchased from Sigma-Aldrich Chemie Gmbh (Tufkirchen, Germany), while 7-Amino-actinomycin D (7-AAD) and recombinant rat IL-2 were obtained from BD Biosciences Pharmingen (Mountain View, CA, USA).

Phenol red-free RPMI-1640 medium (with L-glutamine) was obtained from Gibco (Invitrogen Corporation, Carlsbad, CA, USA). To prepare complete RPMI medium 25 mM N-2-hydroxyethylpiperazine-N-2-ethanesulfonic acid (HEPES) (Sigma-Aldrich Chemie Gmbh), $1 \mathrm{mM}$ sodium pyruvate (Serva, Heidelberg, Germany), 100 units $/ \mathrm{mL}$ penicillin (ICN, Costa Mesa, CA, USA), $100 \mathrm{mg} / \mathrm{mL}$ streptomycin (ICN) and 10\% inactivated fetal calf serum (FCS) (Gibco, Grand Island, NY, USA) were added.

The following monoclonal antibodies (mAbs) were used: PE-conjugated anti-CD4 (clone OX-38) and FITC-conjugated anti-CD8 (clone OX-8). All these mAbs and isotype IgG controls were purchased from BD Biosciences Pharmingen.

\section{Preparation of single-cell suspensions}

For single-cell suspensions, thymi were dissociated by grinding on a sterile $60-\mu \mathrm{m}$ sieve screen submerged in ice-cold phosphate-buffered saline (PBS), $\mathrm{pH}$ 7.4, supplemented with $2 \% \mathrm{FCS}$ and $0.01 \% \mathrm{NaN}_{3}$ (FACS buffer). The cell suspensions were numerated using an improved Neubauer hemacytometer and trypan blue dye to exclude non-viable cells. Cell density was adjusted to $1 \times 10^{7}$ cells $/ \mathrm{mL}$ by addition of FACS buffer.

\section{Flow cytometric analysis (FCA)}

Analysis of thymocyte apoptosis

Thymocyte apoptosis was measured in freshly isolated thymocyte suspensions and in thymocyte cultures. A total of $2 \times 10^{5}$ cells/well of thymocytes was cultivated in 96-well flat-bottom plates (NuncA/S, Roskilde, Denmark) in phenol red-free RPMI 1640 for 18h. The frequency of apoptotic cells within the entire thymocyte population, and within the major thymocyte subsets was determined using 7-AAD staining as previously described (Perišić et al., 2012). Briefly, aliquots of single cell suspensions of thymocytes $\left(0.5 \times 10^{6}\right.$ cells) were 
Arsenović-Ranin Nevena: Thymocyte apoptosis and proliferation modeling during rat

thymic involution is influenced by ovarian hormones in a thymocyte subset-specific manner

incubated with PE-conjugated anti-CD4 and FITC-conjugated anti-CD8 mAb cocktail for $30 \mathrm{~min}$ and washed in cold PBS to remove the excess Abs. Next, the cells were incubated with DNA binding dye 7-AAD $(5 \mu \mathrm{L})$ at $4^{\circ} \mathrm{C}$ for $20 \mathrm{~min}$, and subsequently analyzed on a FACScan flow cytometer using CELLQuest ${ }^{\mathrm{TM}}$ software (BD Biosciences). According to the intensity of 7-AAD fluorescence, live (7-AAD $\left.{ }^{\text {dull }}\right)$, early apoptotic $\left(7-A A D^{\text {dim }}\right)$ and late apoptotic thymocytes (7-AAD bright) were delineated within each of four thymocyte subsets identified by plotting CD4 vs CD8 expression. It is noteworthy that: i) 7-AAD analysis closely matches with merocyanine 540 (Perisic et al., 2010) and FITC-annexinV (Donner et al., 1999; Gogal et al., 2000) and ii) this assay was superior to propidium iodide and forward/side scatter analysis (Donner et al., 1999; Gogal et al., 2000).

\section{Analysis of thymocyte proliferation}

The frequency of proliferating cells (cells in $S+G 2 / M$ phases of cell cycle) was measured in freshly isolated thymocyte suspensions. The cells were subjected to triple 7-AAD DNA (to identify proliferating cells) and CD4/CD8 thymocyte surface antigen labeling (Rabinovitch et al., 1986). Briefly, aliquots of $0.5 \times 10^{6} \mathrm{cells} / \mathrm{mL}$ were incubated with a cocktail of anti-CD4 PE and anti-CD8 FITC mAbs for $30 \mathrm{~min}$ and washed in cold PBS to remove the excess Abs. Subsequently, the pellet was resuspended in $150 \mu \mathrm{L} 50 \%$ FCS in PBS and the cells were fixed/permeabilized by dropwise addition of $450 \mu \mathrm{L}$ of cold $70 \%$ ethanol in double distilled $\mathrm{H}_{2} \mathrm{O}$ while gently mixing. This technique provides the necessary permeabilization of cell membranes for accurate measurement of DNA content with minimal loss of Ag surface expression and Ag-Ab association. The cells were incubated overnight, washed twice with cold PBS to remove the ethanol and precipitated protein and incubated with 7-AAD $(10 \mu \mathrm{L})$ at $4^{\circ} \mathrm{C}$ for 30 min before analysis on FACScan flow cytometer (Becton Dickinson) using CELLQuest ${ }^{\mathrm{TM}}$ software (BD Biosciences). Doublets were excluded by analyzing the correlated area against width signals of the 7-AAD fluorescence on doublet discrimination module (DDM) dot plot.

Statistical analysis

All data are presented as means \pm SEM. The age-related differences were assessed using Student's unpaired t-test. To assess statistical significance of influence of peripubertal ovariectomy and aging on thymocyte apoptosis and proliferation (ovariectomy $x$ aging), two-way ANOVA followed by the Bonferroni test for post hoc comparisons was used. All analyses were performed with GraphPad Prism 5 software (GraphPad Software, Inc., La Jolla, CA, USA) with the significance level set at $p<0.05$.

\section{RESULTS}

Effects of ovarian hormone deprivation on thymic cellularity

The withdrawal of ovarian hormones at the age of 30 days led to higher $(p<0.001)$ thymocyte yields in both young $\left(213.93 \times 10^{7} /\right.$ thymus $\pm 8.03 \times 10^{7} /$ thymus in Ox rats vs $104.03 \times 10^{7}$ /thymus $\pm 3.43 \times 10^{7} /$ thymus in controls) and 
middle-aged $\left(49.41 \times 10^{7} /\right.$ thymus $\pm 1.84 \times 10^{7} /$ thymus in Ox rats vs $14.85 \times 10^{7}$ / thymus $\pm 1.68 \times 10^{7} /$ thymus in controls) rats, but this rise was more prominent [ovariectomy $x$ age, $F(1,20)=68.84, p<0.001$ ] in middle-aged rats.

Irrespective of ovarian hormone presence, a prominent decline in thymic cellularity was observed $(p<0.001)$ between the ages of 2 and 11 months, but it was less pronounced in Ox (approx. $23 \%$ of that in young adult rats) than in control rats (approx. $14 \%$ of that in young adult rats).

Effects of ovarian hormone deprivation on thymocyte apoptosis

Next, we examined thymocyte apoptosis. Given that it is often difficult to detect the effects of experimental interventions on thymocyte apoptosis because of rapid clearance of apoptotic cells by phagocytes in vivo (Kamath et al., 1998; Okasha et al., 2001), we examined cell apoptosis not only in freshly isolated thymocyte suspensions, but also in 18-hour thymocyte cultures (Fig. 1).

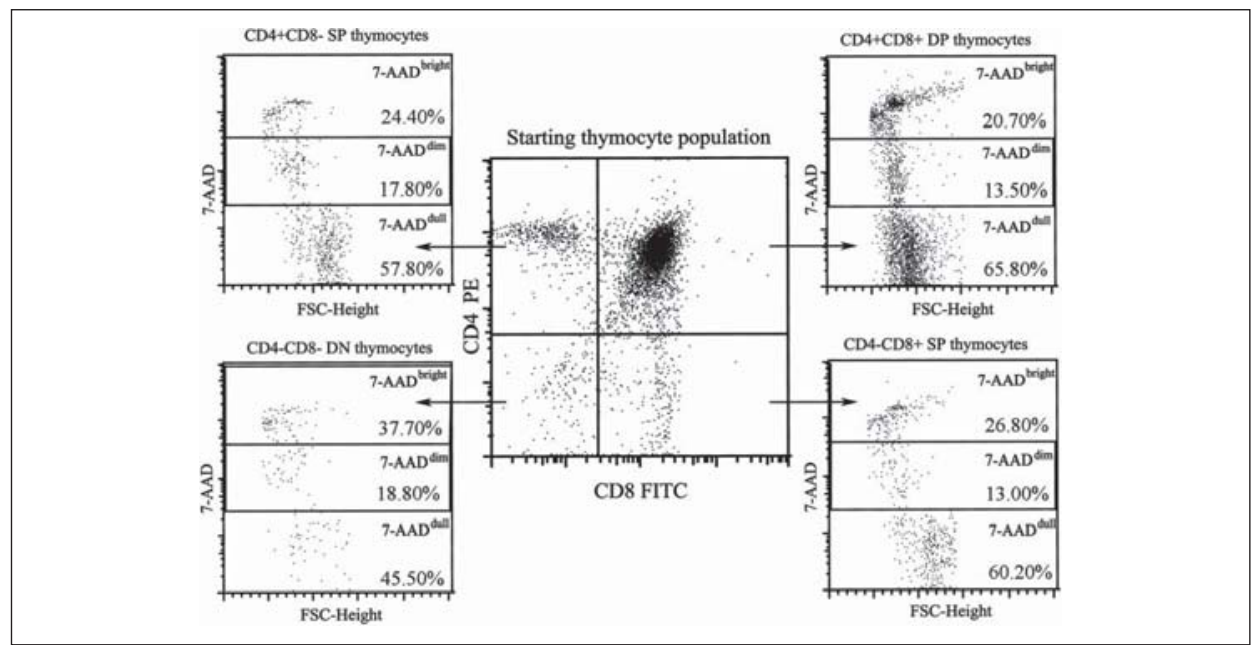

Figure 1. Representative flow cytometry profile demonstrating cell apoptosis within the major thymocyte subsets in 18-hour thymocyte culture from control young adult rats. Representative dot-plots generated by flow cytometry analysis software indicate 7AAD staining of the major thymocyte subsets (CD4-CD8-, CD4+CD8+, CD4-CD8+, CD4-CD8+) gated as shown in (central) flow cytometry dot-plot illustrating CD4 vs CD8 thymocyte surface labeling. Samples were examined for three degrees of 7-AAD staining intensity: 7-AADdull (live cells), 7-AADdim (early apoptotic cells) and 7AAD bright (late apoptotic cells) were delineated within distinct thymocyte subsets. Total apoptosis $=$ early + late apoptosis

\section{Thymocyte apoptosis in fresh thymocyte suspensions}

Comparing with fresh thymocyte suspensions from age-matched control rats, a markedly lower $(p<0.001)$ frequency of apoptotic cells was found only in thymocyte suspensions isolated from young adult ovarian hormone deprived rats [ovariectomy $x$ age interaction, $F(1,20)=59.96, p<0.001$ ]. This decrease could 
Arsenović-Ranin Nevena: Thymocyte apoptosis and proliferation modeling during rat

thymic involution is influenced by ovarian hormones in a thymocyte subset-specific manner

be ascribed to the diminished $(p<0.001)$ frequency of cells in late apoptosis (Fig. 2B). Differently from control suspensions, in thymocyte suspensions from Ox rats an age-dependent rise $(p<0.001)$ in the overall frequency of apoptotic cells was found (Fig. 2A). This rise reflected the increase in the frequencies of thymocytes in both early $(p<0.001)$ and late phases $(p<0.01)$ of apoptosis with age (Fig. 2B). On the other hand, in thymocyte suspensions from control rats, due to the agerelated decrease $(p<0.001)$ in the frequency of cells in late apoptosis, the overall frequency of apoptotic cells was lower $(p<0.01)$ in thymocyte suspensions from middle-aged than those from young rats (Fig. 2B).

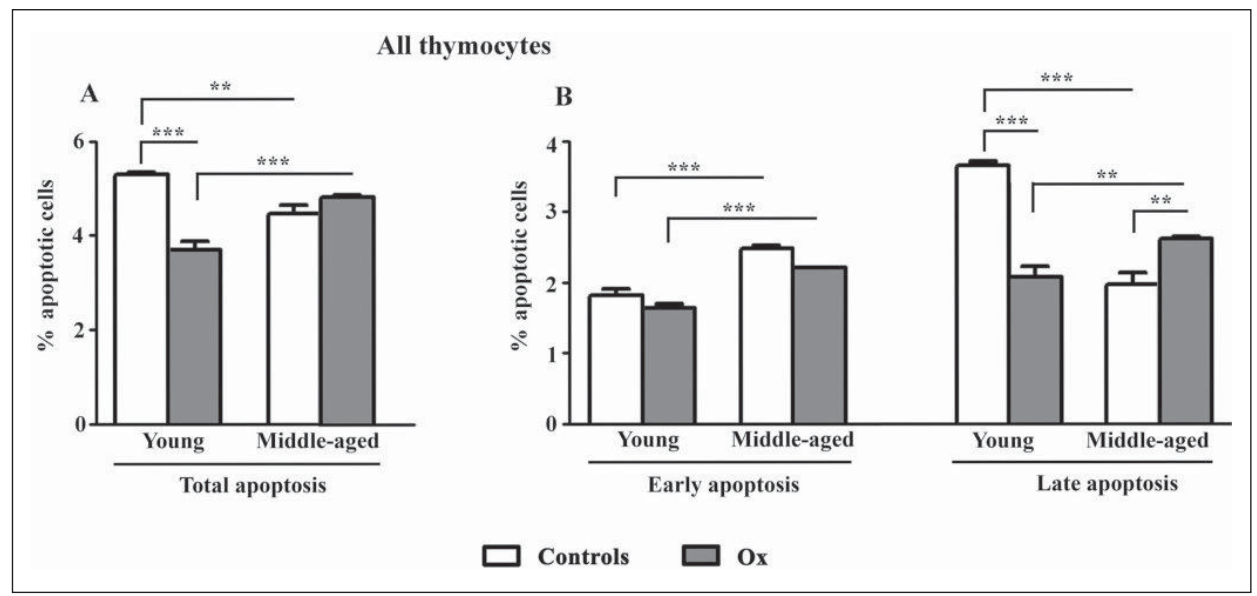

Figure 2. Ovarian hormone withdrawal diminished the percentage of apoptotic cells in freshly isolated thymocyte suspensions. The bar graphs represent the percentage of (A) all apoptotic cells and (B) percentages of cells in (left) early and (right) late phase of apoptosis in fresh thymocyte suspensions from young and middle-aged rats ovariectomized at the age of one month (Ox) and age-matched controls (Controls). The figure shows representative results from three independent experiments. Data are presented as mean \pm SEM. $(n=6) ;{ }^{* *} p<0.01 ;{ }^{* \star *} p<0.001$

\section{Thymocyte apoptosis in culture}

Compared with age-matched controls, the overall frequency of cells undergoing apoptosis was diminished in 18-hour thymocyte cultures from both young $(p<0.001)$ and middle-aged $(p<0.05)$ Ox rats, but to a greater extent [ovariectomy $x$ age interaction, $F(1,20)=5.07, p<0.05$ ] in those from young ones (Fig. 3A). The decrease in the frequency of apoptotic cells in thymocyte cultures from Ox rats of both ages reflected the diminished $(p<0.01)$ frequency of cells in early apoptosis. A more pronounced decrease in the frequency of apoptotic cells in thymocyte cultures from young Ox rats than in those from middle-aged rats when compared with their age-matched control cultures, was related to a decrease in the frequency of cells in late apoptosis, which was registered only in young rats [ovariectomy $x$ age interaction, $F(1,20)=13.19, p<0.01$ ] (Fig. 3B). 
Acta Veterinaria (Beograd), Vol. 63, No. 1, 3-21, 2013.

Arsenović-Ranin Nevena: Thymocyte apoptosis and proliferation modeling during rat thymic involution is influenced by ovarian hormones in a thymocyte subset-specific manner
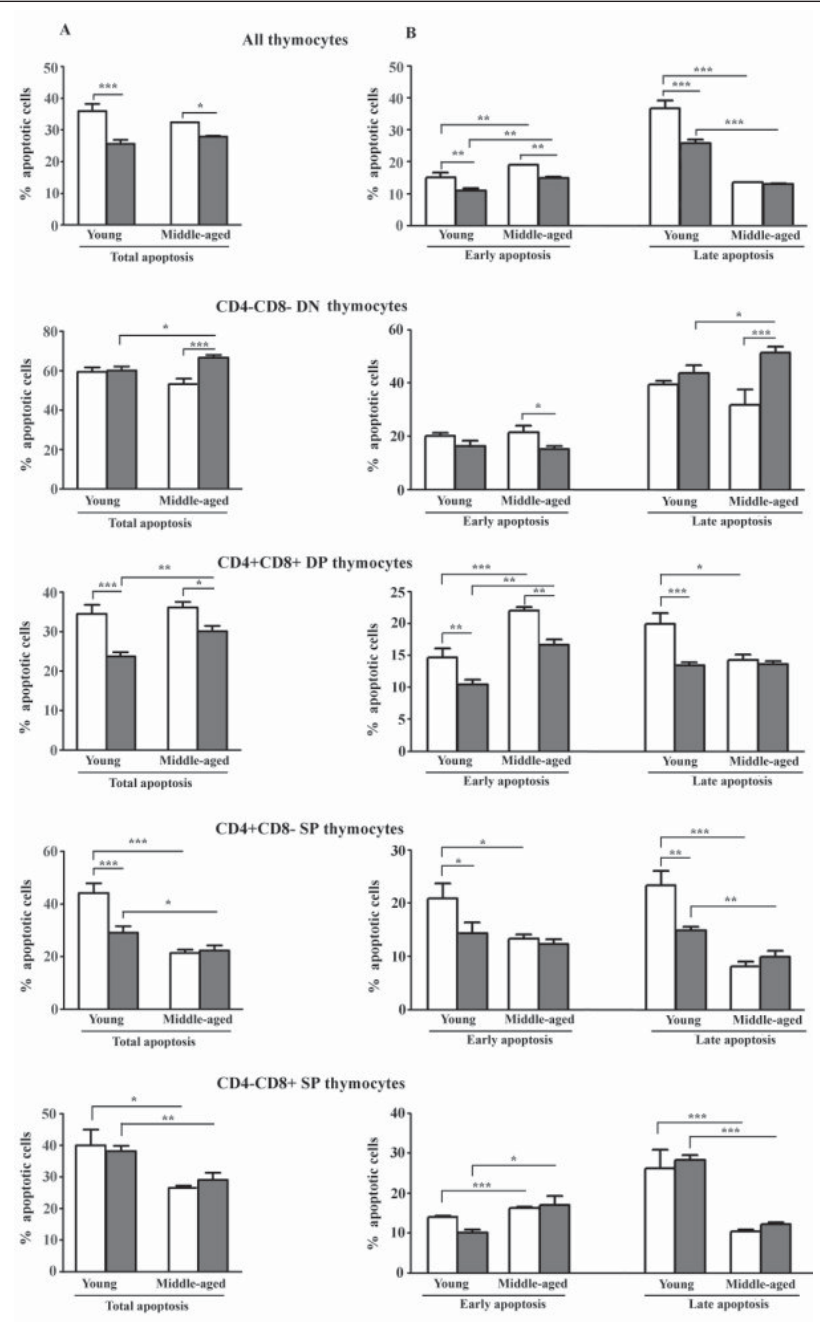

口Controls $\square$ ox

Figure 3. Ovarian hormone withdrawal exerted thymocyte subset-specific and agedependent effects on cell apoptosis in thymocyte cultures. (Panel A) The bar graphs represent the percentage of all apoptotic cells and percentages of apoptotic cells within distinct thymocyte subsets delineated by CD4 vs CD8 expression (CD4-CD8-, CD4+CD8+, CD4-CD8+, CD4-CD8+) in 18-hour thymocyte cultures from young and middle-aged rats ovariectomized (Ox) at the age of one month (Ox groups) and age-matched control rats (Controls). (Panel B) The graph bars indicate the percentage of apoptotic cells in (left) early and (right) late phase of apoptosis within the whole thymocyte population and the major thymocyte subsets in thymocyte cultures from young and middle-aged $\mathrm{Ox}$ (Ox groups) and age-matched control rats (Controls). The figure shows representative results from three independent experiments. Data are expressed as mean \pm SEM. $(n=6) ; p<0.05 ;{ }^{\star *} p<0.01$; $\star * * p<0.001$ 
Acta Veterinaria (Beograd), Vol. 63, No. 1, 3-21, 2013.

Arsenović-Ranin Nevena: Thymocyte apoptosis and proliferation modeling during rat

thymic involution is influenced by ovarian hormones in a thymocyte subset-specific manner

Irrespective of the ovarian hormone presence, the overall frequency of apoptotic cells in thymocyte cultures was not influenced by donor age. Namely, with age in thymocyte cultures from both $O x$ and control rats the frequency of cells in early apoptosis increased $(p<0.01)$, whereas that of the cells in late apoptosis decreased $(p<0.001)$, so the overall frequency of apoptotic cells was comparable in thymocyte cultures from young and middle-aged rats (Fig. 3B).

Apoptosis within the major thymocyte subsets

To determine the stage of differentiation at which thymocytes were most susceptible to ovarian hormone-induced apoptosis, we examined the frequency of apoptotic cells within different thymocytes subsets delineated by CD4/CD8 surface expression.

Compared with control cultures from age-matched rats, the frequency of apoptotic cells within DN subset was unaltered in thymocyte cultures from young Ox rats, whereas it was increased $(p<0.001)$ in those from middle-aged Ox rats [ovariectomy $x$ age interaction, $F(1,20)=9.05, p<0.01$ ], due to a higher $(p<0.001)$ frequency of cells in late apoptosis (Fig. 3A, B). In addition, differently from control cultures, in thymocyte cultures from Ox rats the age-related increase $(p<0.05)$ in the overall frequency of apoptotic cells amongst DN thymocytes was found (Fig. 3A). This increase reflected a higher $(p<0.05)$ frequency of cells in late apoptosis (Fig. 3B).

The overall frequency of apoptotic cells amongst DP thymocytes was diminished in thymocyte cultures from both young $(p<0.001)$ and middle-aged $(p<0.05)$ Ox rats in respect to corresponding age-matched control thymocyte cultures, but this decrease was more prominent in young rats [ovariectomy $x$ age interaction, $F(1,20)=8.62, p<0.01$ ] (Fig. 3Ac). In thymocyte cultures from Ox rats the decrease in the overall apoptosis reflected diminished frequency of cells in both early $(p<0.01)$ and late $(p<0.001)$ apoptosis and in early apoptosis $(p<0.01)$ in young and middle-aged rats, respectively (Fig. 3Bc). Furthermore, differently from control cultures, where the overall frequency of apoptotic cells was not influenced by donor animal age, in thymocyte cultures from Ox rats an agerelated increase $(p<0.01)$ in the overall frequency of apoptotic cells amongst DP thymocytes was found (Fig. 3A). This increase reflected a higher $(p<0.01)$ frequency of cells in early apoptosis in thymocyte cultures from middle-aged compared with young adult rats (Fig. 3A).

Ovariectomy led to significant changes in the overall frequency of apoptotic CD4+CD8- SP cells within CD4+CD8- SP subset only in thymocyte cultures from young rats [ovariectomy $x$ age interaction, $F(1,20)=10.26, p<0.01$ ]. The overall frequency of apoptotic cells) amongst CD4+CD8- SP cells was diminished $(p<0.001)$ in thymocyte cultures from young Ox rats (Fig. 3A). This reflected the reduction in the frequency of cells in both early $(p<0.05)$ and late $(p<0.01)$ apoptosis (Fig. 3B). In thymocyte cultures from both control $(p<0.001)$ and $O x$ $(p<0.05)$ rats the age-related decreases in the overall frequency of apoptotic cells were measured (Fig. 3A). The age-related decline in the overall frequency of apoptotic cells within CD4+CD8- SP subset in thymocyte cultures from Ox rats reflected a decrease $(p<0.01)$ in the frequency of cells in late apoptosis, whereas 
that in control rats was related to the diminished frequencies of cells in both early $(p<0.05)$ and late $(p<0.001)$ apoptosis (Fig. 3B).

Differently from other thymocyte subsets, the overall frequency of apoptotic cells amongst the CD4-CD8 + SP cells was not significantly affected in thymocyte cultures from Ox rats compared with age-matched control cultures (Fig. 3A). However, in thymocyte cultures from both $O x(p<0.01)$ and control $(p<0.05)$ rats, an age-dependant decrease in the overall frequency of apoptotic cells amongst CD4-CD8+ thymocytes was found. This reflected dramatic age-related decline $(p<0.001)$ in the frequencies of cells in late apoptosis, since the frequencies of cells in early apoptosis increased in both $O x(p<0.05)$ and control $(p<0.001)$ rats with age (Fig. 3B).

Effects of ovarian hormone deprivation on thymocyte proliferation

To elucidate the role of ovarian hormones in shaping the age-related changes in thymocyte proliferative capacity, we measured the frequency of proliferating cells (cells in $S+G 2 / M$ phases of the cell cycle) within the major thymocyte subsets using 7-AAD staining (Fig. 4).

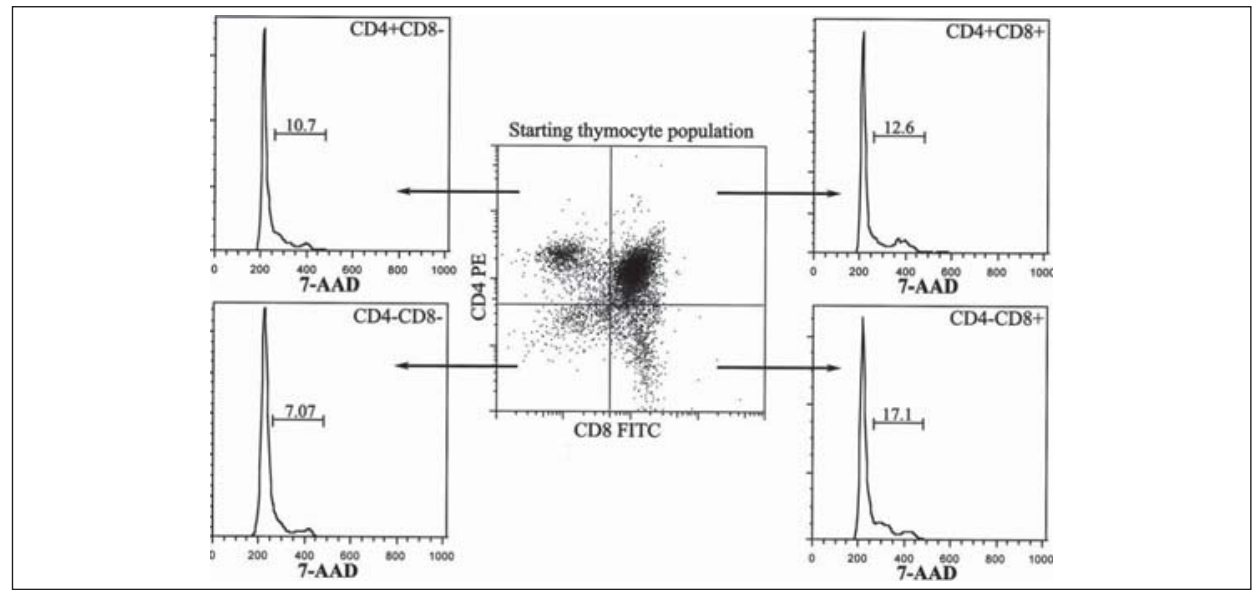

Figure 4. Representative flow cytometry profiles generated by cell cycle analysis of 7-AAD staining of the major thymocyte subsets in fresh thymocyte suspensions.

The flow cytometry histograms show 7-AAD staining of the major thymocyte subsets (CD4-CD8-, CD4+CD8+, CD4-CD8+, CD4-CD8+) from young adult control rats gated as shown in (central) flow cytometry dot-plot illustrating CD4/CD8 thymocyte surface labeling. In all histograms, the bar indicates proliferating cells (cells in $\mathrm{S}+\mathrm{G} 2 \mathrm{M}$ phases of cell cycle)

Ovariectomy diminished thymocyte proliferation in both young $(p<0.01)$ and middle-aged rats $(p<0.001)$, but this effect of ovariectomy was more pronounced in middle-aged rats [ovariectomy $x$ age interaction, $F(1,20)=4.40$, $p<0.05$ ] (Fig. 5). In thymocyte suspensions from both Ox $(p<0.001)$ and control 
Acta Veterinaria (Beograd), Vol. 63, No. 1, 3-21, 2013.

Arsenović-Ranin Nevena: Thymocyte apoptosis and proliferation modeling during rat

thymic involution is influenced by ovarian hormones in a thymocyte subset-specific manner

rats $(p<0.05)$ the age-related decline in the frequency of proliferating cells was detected (Fig. 5).

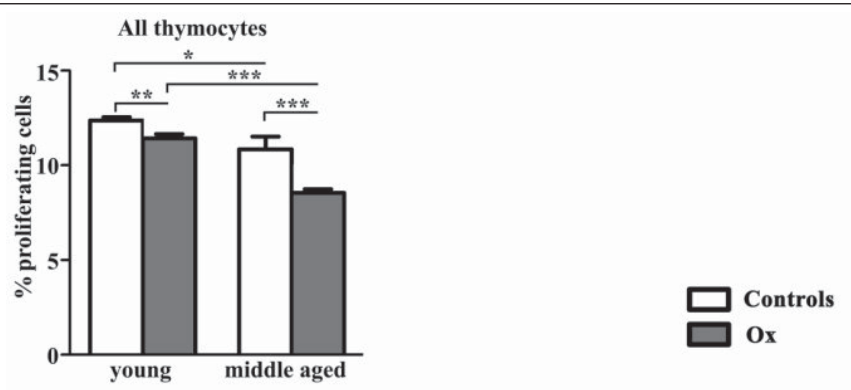

CD4-CD8- DN thymocytes

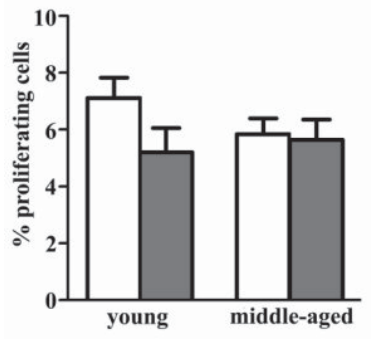

CD4+CD8- SP thymocytes

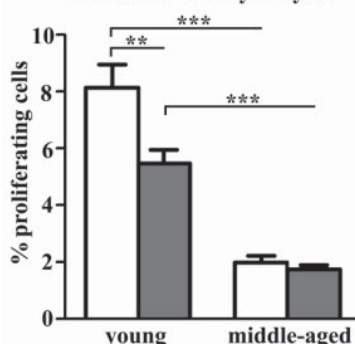

CD4+CD8+ DP thymocytes

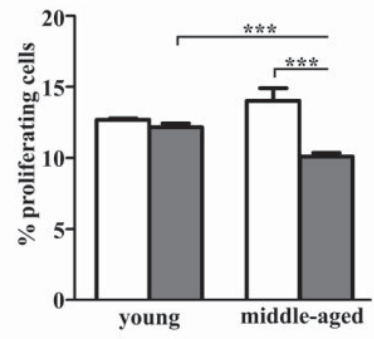

CD4-CD8+ SP thymocytes

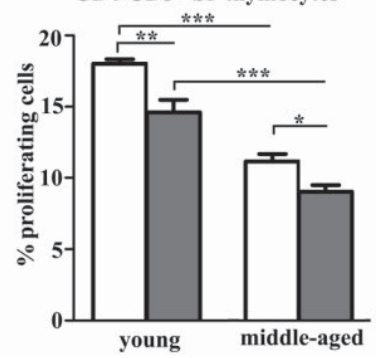

Figure 5. Ovarian hormone withdrawal affected the percentage of proliferating cells in a thymocyte subset-specific and age-dependent manner.

The bar graphs represent the percentage of proliferating cells (cells in $S+G 2 / M$ phases of cell cycle identified by 7-AAD staining) within (panel A) whole freshly isolated thymocyte population and (panel B) the major thymocyte subsets delineated by CD4/CD8 expression (CD4-CD8- DN, CD4+CD8+ DP, CD4+CD8- SP and CD4CD8+ SP thymocytes) from young adult and middle-aged rats ovariectomized at age of 1 month (Ox groups) and from their age-matched counterparts (Controls). The figure shows representative results from three independent experiments. The data are expressed as mean \pm S.E.M. $(n=6){ }^{\star} p<0.05 ;{ }^{\star \star} p<0.01 ;{ }^{* \star} p<0.001$ 
Thymocyte proliferation in distinct thymocyte subsets

Next, to identify thymocyte subset/s, which is/are particularly sensitive to the withdrawal of ovarian hormones, we examined the frequency of proliferating cells within each of four thymocyte subsets delineated by CD4/CD8 expression.

In freshly prepared thymocyte suspensions, the frequency of proliferating cells in DN subset was influenced by neither ovariectomy nor aging.

In DP thymocyte subset we detected ovariectomy-induced decrease $(p<0.001)$ in the frequency of proliferating cells only in thymocyte suspensions freshly isolated from middle-aged rats [ovariectomy $x$ age interaction, $F(1,20)=$ $12.30, p<0.01$ ] (Fig. 5). Furthermore, in thymocyte suspensions from Ox rats we detected the age-related decline $(p<0.001)$ in the frequency of proliferating cells amongst DP thymocytes, whereas the frequency of these cells remained stable in DP subset from control rats (Fig. 5).

Ovariectomy influenced the frequency of proliferating cells only within CD4+CD8- SP cell subset in thymocyte suspensions from young rats [ovariectomy $x$ age interaction, $F(1,20)=6.02, p<0.05$ ]. In these suspensions the frequency of proliferating cells amongst CD4+CD8- SP thymocytes was lower $(p<0.01)$ than in the corresponding control suspensions (Fig. 5). The frequency of proliferating cells amongst CD4+CD8- SP subset exhibited age-related decline $(p<0.001)$ in thymocyte suspensions from both Ox and control rats (Fig. 5).

In thymocyte suspensions from both young $(p<0.01)$ and middle-aged $(p<0.05)$ Ox rats, the frequency of proliferating cells within CD4-CD8+ thymocyte subset was diminished compared with age-matched controls (Fig. 5). Besides, the frequencies of proliferating cells amongst CD4-CD8+ cells in thymocyte suspensions from both $O x$ and control middle-aged rats were lower $(p<0.001)$ than in thymocyte suspensions from their young counterparts (Fig. 5).

\section{DISCUSSION}

The study showed that the ovarian hormones withdrawal before puberty significantly diminished the overall thymocyte apoptosis and proliferation in young sexually mature rats. The values of these thymocyte indices remained lower in middle-aged $\mathrm{Ox}$ than in age-matched controls. Furthermore, the withdrawal of ovarian hormones leads to differential effects on distinct thymocyte subsets. This seems to be quite expectable if one considers the following facts. Firstly, there is differential expression of classical intracellular estrogen receptors and membrane G protein-coupled receptor 30 (GPR30) across thymocyte subsets (Leposavic and Perisic, 2008). Secondly, distinct thymocyte subsets reside in substantially different microsurroundings (Takahama, 2006). Thirdly, ovarian hormones are shown to influence specific subpopulations of thymic stromal cells, which, in turn, may influence thymocyte apoptotic and proliferative capacity (Leposavic and Perisic, 2008). Finally, the effects of estrogens on immune cells are dependent on: i) the cell type/maturation and its specific microenvironment, ii) the expression of estrogen receptor subtypes and iii) the concentration of estrogens (Straub, 2007). 
Acta Veterinaria (Beograd), Vol. 63, No. 1, 3-21, 2013.

Arsenović-Ranin Nevena: Thymocyte apoptosis and proliferation modeling during rat

thymic involution is influenced by ovarian hormones in a thymocyte subset-specific manner

\section{Thymocyte apoptosis}

The lower frequency of apoptotic cells in thymocyte suspensions and in 18hour thymocyte cultures from young Ox rats compared with age-matched controls is in agreement with data showing that: i) estrogen enhances in vitro murine thymocyte apoptosis (McMurray et al., 2000) and ii) the extended exposure of adult female mice to supraphysiological levels of $17 \beta$-estradiol or to low doses of diethylstilbestrol (DES) increases the percentage of apoptotic cells in fresh thymocyte suspensions (Zajchowski et al., 2000; Calemine et al., 2002). In addition, the exposure to pharmacological levels of $\beta$-estradiol leads to greater frequency of apoptotic thymocytes and Fas/FasL mRNA levels in thymi from female rats (Yao and $\mathrm{Hou}, 2004$ ).

Unlike in thymocyte cultures from middle-aged Ox rats, where the frequency of apoptotic cells was lower than in those from age-matched controls, there was no significant difference in the frequency of apoptotic cells in fresh thymocyte suspensions from the same animals. Furthermore, differently from thymocyte cultures (where the frequency of apoptotic cells was stable irrespective of donor age and ovarian hormone presence), the frequencies of apoptotic cells in freshly prepared thymocyte suspensions from $\mathrm{Ox}$ and control rats exhibited age-related increase and decrease, respectively. Different patterns of the age-associated changes in thymocyte apoptosis amongst freshly isolated and cultured thymocytes from control rats could be related to an age-related increase in macrophage phagocytic activity (Stout and Suttles, 2005; Nishioka and Hosokawa, 2010), leading to a more efficient elimination of apoptotic cells in the thymus. The substantial decrease in the frequency of cells in late apoptosis in fresh thymocyte suspensions from middle-aged compared with young controls may be taken as indicative of the enhanced macrophage phagocytosis in older animals. Differential pattern of age-related changes in the frequency of apoptotic cells in fresh thymocyte suspensions from Ox rats and in their cultures could be explained by data combining two lines of evidence. First, that estrogen influences macrophage phagocytosis (Chao et al., 1996; Salem et al., 1999). Second, that there is a gradual increase in the circulating estrogen level after ovariectomy in rats, due to the augmented adrenal production and peripheral aromatization of adrenal androgens (Zhao et al., 2005).

Moreover, our results showed that the withdrawal of ovarian hormones affected thymocyte apoptosis in a thymocyte subset-specific manner. In favor of this finding are data indicating that both DES administration to adult female rats and exposure to this estrogenic compound during foetal development lead to the cell subset-specific changes in thymocyte apoptosis (Calemine et al., 2002; Besteman et al., 2005). Considering the ovariectomy-induced effects on thymocyte apoptosis across distinct thymocyte subsets in culture, it seems clear that the decrease in the frequency of apoptotic cells among the most numerous DP thymocytes mostly contributed to the diminished frequency of apoptotic cells in thymocyte cultures from Ox rats of both ages. This is consistent with the data indicating that DES augments female murine DP cell apoptosis in a dosedependent manner (Calemine et al., 2002). Further support for this finding comes from data showing that: i) DP cells are extremely sensitive to various apoptotic 
stimuli in vitro, most likely, due to the constitutive activation of the E2F-1 transcription factor (Xue et al., 2010) and ii) signaling via estrogen receptor a enhances the expression of E2F1 (Louie et al., 2010). It should be also pointed that the downregulation of Fas/Fas ligand signaling complex component expression in DP thymocytes, as a consequence of insufficient estrogen stimulation through classical intracellular estrogen receptor, could also contribute to the diminished apoptosis of these cells in Ox rats (Mor et al., 2002; Yao and Hou, 2004). Moreover, given that in the presence of low level of endogenous estradiol, GPR30-mediated estrogen signaling might exert an anti-apoptotic effect on DP thymocytes, by altering $\mathrm{Ca}^{2+}$ influx and mobilization from intracellular reservoirs (Revankar et al., 2005; Wang et al., 2008), it may be speculated that this mechanism also contributed to the lower apoptosis within heterogeneous (in terms of differentiation/maturation) DP subset from Ox rats. The age-related increase in the frequency of apoptotic cells within this cell subset in thymocyte cultures from Ox rats could be related to the aforementioned gradual increase of the circulating estrogen levels following ovariectomy (Zhao et al., 2005).

In keeping with data showing that phytoestrogens induce apoptosis selectively in CD4+CD8- SP and DP thymocytes in adult mice (Yellayi et al., 2002), we measured the higher frequency of apoptotic cells amongst CD4+CD8- SP cells in thymocyte cultures from young Ox rats. The frequency of apoptotic cells within this subset in thymocyte cultures from Ox, as in those from control rats, continued to decrease with age. This finding is consistent with the data indicating that thymocytes in aged animals acquire resistance to apoptosis with maturation (Palmers et al., 2009). This is most likely a compensatory mechanism acting to sustain the numbers of recent thymic emigrants in the periphery that declines with age (Palmers et al., 2009). In keeping with this assumption, we found an agerelated decrease in the frequency of apoptotic cells within CD4-CD8+ subset in thymocyte cultures from both Ox and control rats.

Finally, the frequency of apoptotic cells was higher in a small subset of the most immature DN cells in thymocyte cultures from middle-aged Ox rats than in age-matched controls. This most likely reflected the influence of ovarian hormone deprivation on the microenvironment supporting DN cell survival and differentiation. In favor of this hypothesis are our unpublished data that cortical thymic epithelial component in rats exhibits more profound changes between the ages of 2 and 11 months in the Ox than in control rats.

\section{Thymocyte proliferation}

The study also demonstrated that the frequency of proliferating cells is substantially lower in thymocyte suspensions freshly isolated from Ox rats of both ages then in their age-matched controls. This finding is consistent with data showing that in Balb/c mice single injection of $17-\beta$-estradiol, as well as pregnancy-induced rise in ovarian steroid hormone levels leads to the increase in the percentage of thymocytes in the $\mathrm{M}$ phase of the cell cycle (Brunelli et al., 1992). However, it should be pointed that Zoller et al. (2007) reported the decrease in frequency of BrdU+ cells within all major thymocyte subsets from pregnant $\mathrm{C} 57 \mathrm{BL} / 6$ mice. This obvious discrepancy between the results obtained 
Acta Veterinaria (Beograd), Vol. 63, No. 1, 3-21, 2013.

Arsenović-Ranin Nevena: Thymocyte apoptosis and proliferation modeling during rat

thymic involution is influenced by ovarian hormones in a thymocyte subset-specific manner

in pregnant mice of distinct strains, could be related to: i) genetic differences, ii) different time points during gestation when analysis was performed (on gestation day 2, 10 and 17 in Balb/c and 18.5 in C57BL/6 mice) and iii) the fact that changes in the percentage of cells in the $\mathrm{M}$ phase of the cell cycle and in that of BrdU+ (presumably all cells that incorporated BrdU, including those entering apoptosis) cells were reported in Balb/c and C57BL/6 mice (Brunelli et al., 1992; Zoller et al., 2007), respectively. In favor of the lower thymocyte proliferation in the absence of ovarian hormones there are data that: i) both thymic epithelial cells and macrophages synthesize prostaglandin E2 (PGE2) that acts as a cell proliferation suppressive factor (Hirokawa et al., 1994; Malaguarnera et al., 2001), ii) 17- $\beta$ estradiol negatively regulates PGE2 synthesis in rat uterine tissue (Chaud et al., 1994) and iii) ovariectomy-induced increase in PG synthesis in neonatal mouse bone marrow could be reversed by estrogen replacement (Kawaguchi et al., 1994).

Although it has been previously shown that the extended exposure to high ovarian steroid hormone levels increases the percentage of proliferating cells in all thymocyte subsets from mice (Brunelli et al., 1992; Zoller et al., 2007), ovariectomy-induced decrease in rat thymocyte proliferation achieved statistical significance only within SP subsets from young rats. Given that both DN and DP subsets contain cells at distinct differentiational/maturational stages (Perisic et al., 2010), which possibly exhibit different sensitivity to ovarian hormone action, it may be speculated that their composition in mice and rats differs in respect to cell differentiational/maturational stage, and consequently sensitivity to ovarian hormone action, so that the net effect of ovarian hormones on their proliferation of DN cells differs between these two species. In addition, it should be consider that the ovariectomy-induced changes in thymocyte proliferation could be induced by withdrawal of not only ovarian steroids, but also some non-steroid ovarian hormones, as it is inhibin, exerting stimulatory effects on thymocyte proliferation (Aleman-Muench and Soldevila, 2012). The diminished proliferation of both CD4+CD8- and CD4-CD8+ SP thymocytes in Ox rats could be linked with the higher PGE2 concentration is in thymic medulla, where the most mature SP thymocytes reside (Takahama, 2006), than in the thymic cortex (Hirokawa et al., 1994).

Furthermore, in both control and Ox rats, we found the age-related decline in thymocyte proliferation, which reflected the diminished proliferation of both CD4+CD8- and CD4-CD8+ SP cells. This was consistent with the previous finding showing that murine thymocytes stimulated with ConA (which acts through the TCR) together with interleukin-2 displayed an age-related decline in proliferation (Palmers et al., 2009). We obtained similar data using Wistar rat thymocytes (Leposavic et al., 2006). Moreover, assessing in vivo intrathymic proliferation by employing TCR excision circle (TREC) ratio analysis, it was revealed that only thymocytes in later stages of maturation are affected by aging in humans (Dion et al., 2004). In addition, in Ox rats we also observed a diminished cell proliferation in DP thymocyte subset. It should be pointed that of all thymocytes the least mature cortical DP cells exhibit most extensive proliferation (Surh and Sprent, 1994). Considering that between the ages of 2 and 
11 months more extensive changes in thymic stroma were observed in prepubertally $\mathrm{Ox}$ than in control rats (our unpublished data), it may be speculated that in Ox rats a decreased proliferation of the least mature DP cells, due to more extensive changes in their surrounding, contributed to the lower frequency of proliferating cells within the whole DP thymocyte subset.

In conclusion, the study showed that ovarian hormones contribute to the alterations in the overall rat thymocyte apoptotic and proliferative capacity occurring with thymic involution. Furthermore, it demonstrated that only thymocytes at certain stages of differentiation/maturation embedded in specific cellular and molecular surrounding exhibit sensitivity to ovarian hormone action in terms of modulation of cell apoptotic and proliferative capacity. Moreover, it indicated that the effects of ovarian hormone withdrawal significantly change with age. Given that thymocyte subsets identified by CD4/CD8 expression are heterogeneous in respect to differentiation/maturation, it may be assumed that the age-related changes in the effects of ovariectomy reflected age-related (most likely not only ovarian-hormone dependent), alteration in composition of thymocyte subsets in respect to contribution of cells at distinct developmental stages and/or in intrinsic characteristics of compositing cells. In addition, these changes may be related to the age-related alterations in specific microenvironment supporting distinct stages of thymocyte development. Alternatively, they could reflect the changes in ovarian steroid concentration occurring following ovariectomy in rats. To exclude the latter option, additional experiments using blockers of steroid hormone synthesis and/or action are necessary.

ACKNOWLEDGMENT:

This work was supported by grant 175050 from Ministry of Education and Science of Republic of Serbia.

Address for correspondence:

Professor Gordana Leposavić, MD, PhD

Department of Physiology, Faculty of Pharmacy

University of Belgrade

450 Vojvode Stepe

11221 Belgrade, Serbia

E-mail: gordana.leposavicpharmacy.bg.ac.rs

\section{REFERENCES}

1. Aleman-Muench Gr, Soldevila G, 2012, When versatility matters: activins/inhibins as key regulators of immunity, Immunol Cell Biol, 90, 137-48.

2. Aw $D$, Silva $A B$, Palmer $D B, 2009$, Is thymocyte development functional in the aged?, Aging, 1, 2, 146-53.

3. Besteman EG, Zimmerman KL, Holladay SD, 2005, Diethylstilbestrol (DES)-Induced Fetal Thymic Atrophy in C57BL/6 Mice: Inhibited Thymocyte Differentiation and Increased Apoptotic Cell Death, Int J Toxicol, 24, 231-9.

4. Brunelli R, Frasca D, Bachieri S, Spanò M, Fattorossi A, Mosiello LF, D'Amelio R, Zichella L, Doria G, 1992, Changes in Thymocyte Subsets Induced by Estradiol Administration or Pregnancy, Ann NY Acad Sci, 650, 109-14. 
Arsenović-Ranin Nevena: Thymocyte apoptosis and proliferation modeling during rat thymic involution is influenced by ovarian hormones in a thymocyte subset-specific manner

5. Calemine JB, Gogal RM Jr, Lengi A, Sponenberg P, Ahmed SA, 2002, Immunomodulation by diethylstilbestrol is dose and gender related: effects on thymocyte apoptosis and mitogeninduced proliferation, Toxicology, 178, 2, 101-18.

6. Chao TC, Phuangsab A, Van Alten PJ, Walter RJ, 1996, Steroid sex hormones and macrophage function: regulation of chemiluminescence and phagocytosis, Am J Reprod Immunol, 35, 10613.

7. Chaud M, Faletti A, Beron de Estrada M, Gimeno AL, Gimeno MA, 1994, Synthesis and release of prostaglandins D2 and E2 by rat uterine tissue throughout the sex cycle. Effects of 17-betaestradiol and progesterone, PLEFA, 51, 47-50.

8. Dion ML, Poulin JF, Bordi R, Sylvestre M, Corsini R, Kettaf $N$ et al., 2004, HIV infection rapidly induces and maintains a substantial suppression of thymocyte proliferation, Immunity, 21, 75768.

9. Donner KJ, Becker KM, Hissong BD, Ansar Ahmed S, 1999, Comparison of multiple assays for kinetic detection of apoptosis in thymocytes exposed to dexamethasone or diethylstilbesterol, Cytometry, 35, 80-90.

10. Frasor J, Barnett DH, Danes JM, Hess R, Parlow AF, Katzenellenbogen BS, 2003, Response-specific and ligand dose-dependent modulation of estrogen receptor (ER) alpha activity by ER beta in the uterus, Endocrinology, 44, 7, 3159-66.

11. Gogal RM Jr, Smith BJ, Kalnitsky J, Holladay SD, 2000, Analysis of apoptosis of lymphoid cells in fish exposed to immunotoxic compounds, Cytometry, 39, 310-8.

12. Gruver AL, Hudson LL, Sempowski GD, 2007, Immunosenescence of ageing, J Pathol, 211, 2, 14456.

13. Hirokawa K, Utsuyama M, Kasai M, Kurashima C, Ishijima S, Zeng YX, 1994, Understanding the mechanism of the age change of thymic function to promote T cell differentiation, Immunol Lett, 40, 269-77.

14. Jameson SC, Hogquist KA, Bevan MJ, 1995, Positive Selection of Thymocytes, Annu Rev Immunol, 13, 93-126.

15. Kamath B, Nagarkatti PS, Nagarkatti M, 1998, Characterization of phenotypic alterations induced by 2,3,7,8-tetrachlorodibenzo-p-dioxin on thymocytes in vivo and its effect on apoptosis, Toxicol Appl Pharm, 150, 117-24.

16. Kawaguchi H, Pilbeam CC, Vargas SJ, Morse EE, Lorenzo JA, Raisz LG, 1995, Ovariectomy enhances and estrogen replacement inhibits the activity of bone marrow factors that stimulate prostaglandin production in cultured mouse calvariae, J Clin Invest, 96, 539-48.

17. Leposavic G, Perisic $M, 2008$, Age-associated remodeling of thymopoiesis: role for gonadal hormones and catecholamines, Neuroimmunomodulat, 15, 290-322.

18. Leposavic G, Pesic V, Kosec D, Radojevic K, Arsenovic-Ranin N, Pilipovic I et al., 2006, Ageassociated changes in CD90 expression on thymocytes and in TCR-dependent stages of thymocyte maturation in male rats, Exp Gerontol, 41, 574-89.

19. Linton PJ, Dorshkind K, 2004, Age-related changes in lymphocyte development and function, Nat Immunol, 5, 133-9.

20. Louie MC, McClellan A, Siewit C, Kawabata L, 2010, Estrogen receptor regulates E2F1 expression to mediate tamoxifen resistance, Mol Cancer Res, 3, 343-52.

21. Malaguarnera L, Ferlito L, Di Mauro S, Imbesi RM, Scalia G, Malaguarnera M, 2001, Immunosenescence and cancer: a review, Arch Gerontol Geriat, 32, 2, 77-93.

22. Malaguarnera L, Ferlito L, Imbesi RM, Gulizia GS, Di Mauro S, Maugeri D et al., 2001, Immunosenescence: A review, Arch Gerontol Geriat, 32, 1, 1-14.

23. McMurray RW, Wilson JG, Bigler L, Xiang L, Lagoo A, 2000, Progesterone inhibits glucocorticoidinduced murine thymocyte apoptosis, Int $J$ Immunopharm, 22, 11, 955-65.

24. Mor G, Straszewski S, Kamsteeg M, 2002, Role of the Fas/Fas ligand system in female reproductive organs: survival and apoptosis, Biochem Pharmacol, 64, 1305-15.

25. Nishioka K, Hosokawa T, 2010, Age-associated change in the phagocytic activity of macrophages from SAM mice, Intimm Meeting Abstracts, 22, Suppl 1 Pt 4, 148-52. 
26. Okasha SA, Ryu S, Do Y, McKallip RJ, Nagarkatti M, Nagarkatti PS, 2001, Evidence for estradiolinduced apoptosis and dysregulated T cell maturation in the thymus, Toxicology, 163, 49-62.

27. Pawelec G, Akbar A, Caruso, Solana R, Grubeck-Loebenstein B, Wikby A, 2005, Human immunosenescence: is it infectious?, Immunol Rev, 205, 257-68.

28. Perisic M, Arsenovic-Ranin N, Pilipović I, Kosec D, Pesic V, Radojevic K et al., 2010, Role of ovarian hormones in age-associated thymic involution revisited, Immunobiology, 215, 4, 275-93.

29. Perisic M, Stojic-Vukanic Z, Pilipovic I, Kosec D, Nacka-Aleksic M, Dikic J et al., 2012, Role of ovarian hormones in T-cell homeostasis: From the thymus to the periphery, Immunobiology, doi. 10.1016/j.imbio.2012.05.009.

30. Quaglino D, Ronchetti IP, 2001, Cell death in the rat thymus: a minireview, Apoptosis, 6, 389-401.

31. Rabinovitch PS, Torres RM, Engel D, 1986, Simultaneous cell cycle analysis and two-color surface immunofluorescence using 7-amino-actinomycin D and single laser excitation: applications to study of cell activation and the cell cycle of murine Ly-1 B cells, J Immunol, 136, 2769-75.

32. Revankar CM, Cimino DF, Sklar LA, Arterburn JB, Prossnitz ER, 2005, A transmembrane intracellular estrogen receptor mediates rapid cell signaling, Science, 307, 1625-30.

33. Rose NR, 1994, Thymus function, ageing and autoimmunity, Immunol Lett, 40, 225-30.

34. Salem ML, Matsuzaki G, Madkour GA, Nomoto K, 1999, $\beta$-Estradiol-induced decrease in IL-12 and TNF- $\alpha$ expression suppresses macrophage functions in the course of Listeria monocytogenes infection in mice, Int $J$ Immunopharm, 21, 481-97.

35. Segal J, Troen BR, Ingbar SH, 1985, Effects of age and sex on certain metabolic functions and mitogenic activity in rat thymocytes, Thymus, 7, 211-20.

36. Silverstone AE, Frazier DEJr, Fiore NC, Soults JA, Gasiewicz TA, 1994, Dexamethasone, betaestradiol, and 2,3,7,8-tetrachlorodibenzo-p-dioxin elicit thymic atrophy through different cellular targets, Toxicol Appl Pharm, 126, 248-59.

37. Staples JE, Fiore NC, Frazier DEJr, Gasiewicz TA, Silverstone AE, 1998, Overexpression of the antiapoptotic oncogene, bcl-2, in the thymus does not prevent thymic atrophy induced by estradiol or 2,3,7, 8-tetrachlorodibenzo-p-dioxin, Toxicol Appl Pharm, 151, 200-10.

38. Stout RD, Suttles J, 2005, Immunosenescence and macrophage functional plasticity: dysregulation of macrophage function by age-associated microenvironmental changes, Immunol Rev, 205, 60-71.

39. Straub RH, 2007, The Complex Role of Estrogens in Inflammation, Endocr Rev, 28, 5, 21-574.

40. Surh CD, Sprent J, 1994, T-cell apoptosis detected in situ during positive and negative selection in the thymus, Nature, 372, 100-3.

41. Takahama $Y, 2006$, Journey through the thymus: stromal guides for T-cell development and selection, Nat Rev Immunol, 6, 2, 127-35.

42. Wang C, Dehghani B, Magrisso IJ, Rick EA, Bonhomme E, Cody DB et al., 2008, GPR30 Contributes to Estrogen-Induced Thymic Atrophy, Mol Endocrinol, 22, 636-48.

43. Xue L, Sun Y, Chiang L, He B, Kang C, Nolla H et al., 2010, Coupling of the Cell Cycle and Apoptotic Machineries in Developing T Cells, J Biol Chem, 285, 7556-65.

44. Yao G, Hou Y, 2004, Thymic atrophy via estrogen-induced apoptosis is related to Fas/FasL pathway, Int Immunopharmacol, 4, 2, 213-21.

45. Yellayi S, Naaz A, Szewczykowski MA, Sato T, Woods JA, Chang J et al., 2002, The phytoestrogen genistein induces thymic and immune changes: a human health concern?, P Natl Acad Sci USA, 99, 11, 7716-21.

46. Zajchowski S, Hoffman-Goetz L, 2000, Supraphysiological level of estrogen exposure in vivo increases lymphoid cell death in mice, Life Sci, 66, 15, 1451-9.

47. Zhao H, Tian Z, Hao J, Chen B, 2005, Extragonadal aromatization increases with time after ovariectomy in rats, Reprod Bio Endocrin, 3, 6.

48. Zoller AL, Kersh GJ, 2006, Estrogen induces thymic atrophy by eliminating early thymic progenitors and inhibiting proliferation of $\beta$-selected thymocytes, $J$ Immunol, 176, 7371-8.

49. Zoller AL, Schnell FJ, Kersh GJ, 2007, Murine pregnancy leads to reduced proliferation of maternal thymocytes and decreased thymic emigration, Immunology, 121, 207-15. 
Acta Veterinaria (Beograd), Vol. 63, No. 1, 3-21, 2013.

Arsenović-Ranin Nevena: Thymocyte apoptosis and proliferation modeling during rat

thymic involution is influenced by ovarian hormones in a thymocyte subset-specific manner

\title{
HORMONI OVARIJUMA IMAJU RAZLIČIT UTICAJ NA MODELOVANJE APOPTOZE I PROLIFERACIJE UNUTAR RAZLIČITIH SUBPOPULACIJA TIMOCITA TOKOM INVOLUCIJE TIMUSA
}

\author{
ARSENOVIĆ-RANIN NEVENA, NACKA-ALEKSIĆ MIRJANA, DJIKIĆ JASMINA, \\ PERIŠIĆ MILICA, KOSEC D, PILIPOVIĆ I, STOJIĆ-VUKANIĆ ZORICA \\ i LEPOSAVIĆ GORDANA
}

\begin{abstract}
SADRŽAJ
Cilj istraživanja je bio da se definiše značaj hormona ovarijuma za razvoj promena u apoptozi i proliferaciji timocita tokom involucije timusa. $U$ tom cilju apoptoza i proliferacija timocita ispitivana je kod prepubertetno ovariektomisanih (Ox) mladih (uzrasta 2 meseca) i sredovečnih pacova (uzrasta 11 meseci). Apoptoza je određivana u suspenziji sveže izolovanih timocita i nakon njihove 18časovne kultivacije, a proliferacija u suspenziji sveže izolovanih timocita. Procenat apoptotičnih i proliferišućih ćelija je određivan u celokupnoj populaciji timocita, i unutar glavnih subpopulacija ovih ćelija, koje su razdvojene na osnovu ekspresije CD4/CD8 molekula, metodom protočne fluorocitometrije, korišćenjem 7-aminoaktinomicina D (7-AAD). Procenat ćelija u apoptozi je bio značajno manji u suspenzijama svežih timocita koji su izolovani iz Ox životinja i u njihovim kulturama nego u onim izolovanim iz kontrolnih životinja. Ovaj nalaz je odražavao smanjenu učestalost ćelija u apoptozi u CD4+CD8+ dvostruko pozitivnoj (DP) i CD4+CD8jednostruko pozitivnoj (JP) subpopulaciji timocita kod mladih i u DP subpopulaciji kod sredovečnih Ox pacova. U kulturama timocita koji su izolovani iz sredovečnih Ox pacova uočeno je smanjenje učestalosti ćelija u apoptozi unutar subpopulacija CD4+CD8- i CD4-CD8+ JP timocita, a povećanje unutar DP i CD4-CD8dvostruko negativne (DN) subpopulacije ovih ćelija. Učestalost proliferišućih ćelija je takođe bila niža u suspenzijama timocita izolovanih iz Ox pacova nego u onim izolovanim iz kontrolnih životinja. Ovo je odražavalo smanjenu proliferaciju CD4+CD8- i CD4-CD8+ JP timocita kod mladih, a DP i CD4-CD8+ JP timocita kod sredovečnih pacova. Procentualna zastupljenost proliferišućih ćelija u subpopulacijama JP i DP timocita je bila veća kod mladih nego kod sredovečnih Ox pacova. U zaključku, tokom involucije timusa dolazi do promena u apoptozi i proliferaciji timocita koje su specifične za pojedine subpopulacije timocita i zavisne od prisustva hormona ovarijuma.
\end{abstract}

